\title{
PENGARUH PEMBELAJARAN DARING PENGGUNA PLATFORM DIGITAL TERHADAP PEMECAHAN MASALAH MATEMATIS DAN SIKAP KRITIS SISWA DI MA DAAR EL QOLAM
}

\author{
Dwi Yulianto \\ STKIP La Tansa Mashiro \\ dwiyulianto554@gmail.com
}

\begin{abstract}
ABSTRAK
Penelitian ini dilatarbelakangi oleh penelitian yang dilakukan oleh Kusuma (2020) dalam pembelajaran jarak jauh di masa pandemi Covid-19. Dari penelitian ini diketahui bahwa kemampuan pemecahan matematis siswa rendah. Hal ini menunjukkan bahwa siswa belum memahami bagaimana memecahkan masalah dengan topik di dalam matematika serta kejadian di dalam kehidupan. Penelitian ini bertujuan untuk untuk mengetahui kemampuan pemecahan masalah matematis mana yang lebih baik, dengan Webinar Zoom atau WhatsApp Group dan seberapa efektifnya kedua Platform tersebut dalam Masa Pandemi Covid-19. Penelitian ini dilakukan di MA. Daar El Qolam 1 dan MA. Daar El Qolam 4 dengan sampel penelitian sebanyak 4 kelas yang terdiri dari 96 siswa. Metode yang digunakan dalam penelitian ini adalah quasi eksperimen. Teknik pengumpulan data yaitu tes dan kuesioner. Hasil analisis varian (ANAVA) dua jalur dalam penelitian ini menunjukkan bahwa (1) Kemampuan pemecahan masalah matematis siswa yang belajar dengan pembelajaran daring pengguna Webinar Zoom lebih tinggi dibandingkan dengan siswa dengan pembelajaran daring pengguna platform WhatsApp Group, (2) Terdapat interaksi antara pembelajaran daring pengguna platform digital dengan gender terhadap pemecahan masalah matematis, (3) Kemampuan pemecahan masalah matematis siswa perempuan yang belajar dengan pembelajaran daring pengguna platform Webinar Zoom lebih tinggi daripada pembelajaran daring pengguna platform WhatsApp Group, (4) Kemampuan pemecahan masalah matematis siswa laki-laki yang belajar dengan pembelajaran daring pengguna platform Webinar Zoom lebih tinggi daripada pembelajaran daring pengguna platform WhatsApp Group, (5) Sikap kritis siswa yang belajar dengan pembelajaran daring pengguna platform Webinar Zoom lebih tinggi daripada pembelajaran daring pengguna platform WhatsApp Group
\end{abstract}

Kata Kunci : Gender, Pemecahan Masalah, Kritis, Zoom, WhatsApp.

\section{ABSTRACT}

This research is motivated by research conducted by Kusuma (2020) in distance-learning during the pandemi Covid-19. From this study it is known that students' mathematical solving abilities are low. This shows that students do not understand how to solve problems with topics in mathematics and events in life. This study aims to determine which mathematical problem-solving skills are better, with the Webinar Zoom or WhatsApp Group and how effective the two platform s were during the Covid-19 Pandemi Period. This research was conducted at MA. Daar El Qolam 1 and MA. Daar El Qolam 4 with sample of 4 classes consisting of 96 students. The method used in this study is a quasi-experimental. Data collection techniques are tests and questionnaires. The results analysis two way of variance (ANAVA) showed that (1) Mathematical problem solving ability of students who learn by onlinelearning Zoom Webinar users is higher than students with online-learning WhatsApp Group platform users, (2) There is an interaction between online-learning digital platform users with gender towards mathematical problem solving, (3) The mathematical problem solving ability of female students learning by Zoom Webinar users online-learning is higher than the WhatsApp Group platform user onlinelearning, (4) The mathematical problem solving ability of male students learning by online-learning of 
Zoom Webinar platform users is more higher than online-learning of WhatsApp Group platform users, (5) Critical attitude of students who learn by online-learning of Webinar Zoom platform users is higher than online-learning of WhatsApp Group platform users.

Keywords: Gender, Problem Solving, Critical, Zoom, WhatsApp.

\section{PENDAHULUAN}

Saat ini dunia dikejutkan dengan mewabah nya suatu penyakit yang disebabkan oleh sebuah virus yang bernama corona atau dikenal dengan istilah Covid-19 (Corona Virus diseases19). Virus yang disinyalir mewabah 31 Desember 2019 di Kota Wuhan Provinsi Hubei Tiongkok, saat ini menyebar ke seluruh penjuru dunia dengan sangat cepat sehingga WHO tanggal 11 Maret 2020 menetapkan wabah ini sebagai pandemi global. Ratusan ribu manusia terpapar virus ini di seluruh dunia, bahkan puluhan ribu menjadi korban meninggal. Tercatat Negara-negara yang memiliki kasus tinggi terpapar Covid-19 saat ini adalah Italia, Tiongkok, Spanyol, Amerika Serikat dan Iran dengan tingkat kematian mencapai ribuan orang. Penularan yang sangat cepat dan sulit nya mendeteksi orang yang terpapar karena masa inkubasi Covid19 kurang lebih dua minggu menjadi penyebab banyaknya korban berjatuhan.

Penularan lewat kontak antar manusia yang sulit diprediksi karena kegiatan sosial yang tidak bisa dihindari merupakan penyebab terbesar menyebarnya Covid-19 ini, obat penawar yang belum bisa ditemukan dan membludaknya pasien terpapar Covid-19 menjadi penyebab kematian yang paling tinggi. Rumah sakit dan para medis yang menangani merasa kewalahan sehingga banyak pasien yang tidak tertangani dengan baik. Sulitnya Alat Pelindung Diri (APD) bagi para medis menjadi penyebab pasien berjatuhan termasuk dokter dan para medis lainnya yang juga terpapar Covid-19 sehingga akhirnya meninggal. Rumitnya penanganan wabah ini membuat para pemimpin dunia menerapkan kebijakan yang super ketat untuk memutus mata rantai penyebaran Covid-19. Social distancing menjadi pilihan berat bagi setiap Negara dalam menerapkan kebijakan untuk pencegahan penyebaran Covid-19 karena kebijakan ini berdampak negative terhadap segala aspek kehidupan. Pembatasan interaksi sosial masyarakat dapat menghambat laju pertumbuhan dan kemajuan dalam berbagai bidang kehidupan, namun tidak ada pilihan lain karena cara ini adalah yang paling efektif.

Kebijakan social distancing berakibat fatal terhadap roda kehidupan manusia seperti masalah ekonomi yang paling terasa dampaknya karena hal itu menyentuh berbagai lapisan masyarakat, tersendatnya laju perekonomian yang mengakibatkan tertutupnya kebutuhan 
primer manusia untuk memenuhinya, karena negara akan sangat terbebani jika harus menanggung segala kebutuhan pokok setiap penduduknya. Tak terkecuali di bidang pendidikan ikut juga terdampak kebijakan ini. Keputusan pemerintah yang mendadak dengan meliburkan atau memindahkan proses pembelajaran dari sekolah menjadi di rumah. Peralihan cara pembelajaran ini memaksa berbagai pihak untuk mengikuti alur yang sekiranya bisa ditempuh agar pembelajaran dapat berlangsung dengan pemanfaatan teknologi sebagai media pembelajaran daring (pembelajaran dalam jaringan).

Sebelum melaksanakan penelitian ini, telah dilakukan diskusi dengan guru matematika di lingkungan pondok pesantren Daar El Qolam melalui forum MGMP (Musyawarah Guru Mata Pelajaran) Matematika. Menurut para guru, dalam pelaksanaan pembelajaran jarak jauh ini dalam pengamatan penulis beserta MGMP Matematika menyimpulkan bahwa sikap kritis siswa pada pembelajaran matematika di pesantren Daar El Qolam masih rendah. Indikasi rendahnya sikap kritis tersebut dapat ditemukan di dalam forum diskusi pembelajaran. Pada kompetensi dasar, yaitu tentang hakekat operasi aljabar diskusi guru pada proses pembelajaran melalui media daring dengan menggunakan metode ceramah dan tanya jawab diperoleh data bahwa dari 34 siswa ternyata hanya 10 siswa atau 9.37\% yang mampu memberikan penjelasan mengenai hakikat operasi aljabar, hanya 12 siswa (31.16\%) yang mampu memahami materi belajar. Dari 34 siswa yang terlibat dalam tanya jawab di forum diskusi ternyata hanya 3 siswa (7.89\%) yang mampu mengajukan dan menjawab pertanyaan yang bersifat kritis dan kontekstual.

Akibat rendahnya sikap kritis tersebut pembelajaran menjadi kurang kontekstual, maksudnya masih bersifat hafalan dan kurang berkaitan dengan kehidupan di masyarakat. Akibatnya kemampuan pemecahan siswa terhadap materi belajar juga rendah. Hal ini terbukti dari analisis hasil ulangan harian yang hanya mencapai $30 \%$ tuntas secara klasikal. Selain sikap kritis matematis siswa, tingkat pemecahan masalah yang di alami siswa Daar El Qolam sangat bervariasi hal ini dapat diamati dari indikator: 1) siswa yang mampu memahami masalah sebanyak 15 siswa $(44,11 \%)$, 2) siswa yang mampu merencanakan menyelesaikan masalah sebanyak 14 siswa $(41,17 \%), 3)$ siswa yang mampu melaksanakan perencanaan sebanyak 12 siswa (35,29\%), dan 4) siswa yang mampu menafsirkan hasil sebanyak 10 siswa $(29,41 \%)$. Rendahnya hasil belajar matematika siswa juga dapat dilihat dari pencapaian nilai kriteria ketuntasan minimal yaitu dari jumlah 118 siswa terdapat $82 \%$ siswa yang nilainya tidak 
memenuhi standar ketuntasan pada mata pelajaran matematika. Di mana standar ketuntasan rata-rata 78 .

Faktor-faktor penyebab rendahnya kemampuan pemecahan masalah matematis yaitu tidak kepedulian orang tua terhadap belajar siswa, lingkungan belajar yang kurang mendukung, kurangnya motivasi siswa dan model pembelajaran yang digunakan guru kurang bervariasi. Faktor penyebab yang dominan rendahnya siswa dalam memecahkan masalah matematis yaitu model pembelajaran yang digunakan guru kurang bervariasi. Jika guru menggunakan model pembelajaran yang bervariasi dan dapat memotivasi belajar siswa, dengan senang hati siswa akan semangat dan bersungguh-sungguh dalam mengikuti pembelajaran matematika di kelas.

Berdasarkan uraian di atas dalam kompetensi dasar berikutnya penulis berusaha memanfaatkan platform WhatsApp Group dan Webinar Zoom sebagai media dan sumber belajar. Pada penelitian ini, aplikasi WhatsApp dipilih karena menurut data yang dipublikasikan oleh http://infomuria.umk.ac.id, aplikasi-aplikasi instant atau mobile messengers telah berhasil merengkuh pasar dan digandrungi oleh penduduk dunia tak terkecuali oleh remaja Indonesia. WhatsApp merupakan platform pesan yang dapat digunakan dalam pembelajaran jarak jauh, dimana siswa dikumpulkan di satu grup dan proses pembelajaran dilaksanakan secara pesan baik dengan tulisan, suara maupun gambar. Aplikasi ini digunakan oleh peneliti dikarenakan lebih hemat kuota dan familiar dikalangan siswa, karena rata-rata semua nomor yang dimiliki sudah terkoneksi dengan aplikasi ini.

Menurut Jubile Enterprise (2012) mendefinisikan WhatsApp sebagai aplikasi chatting dimana siswa bisa mengirim pesan teks, gambar, suara, lokasi dan bahkan video ke orang lain dengan menggunakan smartphone apapun. Sedangkan menurut Suryadi (2014) menambahkan jika dilihat dari fungsinya WhatsApp hampir sama dengan aplikasi SMS yang biasa dipergunakan di ponsel lama. Namun, WhatsApp ini tidak menggunakan pulsa seperti biaya SMS pada umumnya. WhatsApp ini menggunakan jaringan internet sesuai dengan perkembangan teknologi yang saat ini terhubung dengan jaringan dan teridentifikasi dengan nomor Handphone (HP). WhatsApp Group tersebut saat ini dijadikan wadah diskusi untuk memecahkan berbagai masalah, pertanyaan dan sesuatu yang penting yang harus disampaikan terhadap orang-orang yang tergabung di dalamnya. Diskusi melalui WhatsApp Group ini sangat membantu penggunanya untuk berkomunikasi dalam pembelajaran jarak jauh. Tapi dalam pelaksanaannya aplikasi ini dikeluhkan oleh beberapa siswa dikarenakan minimnya interaksi 
dan Pengajar cenderung terlalu sering memberikan tugas ketika pembelajaran jarak jauh sehingga siswa merasa terbebani oleh tugas-tugas tersebut.

Selain WhatsApp peneliti juga menggunakan Webinar Zoom Meet merupakan Platform tatap muka yang bersifat Conference dimana guru dan siswa bisa langsung berinteraksi selayaknya bertemu langsung. Dalam Aplikasi ini terdapat banyak fitur mulai dari File sharing dalam format PDF bisa dilakukan dengan mudah. Webinar Zoom Meet menawarkan fasilitas yang paling mudah untuk individu yang mau bergabung dengan conference/Meeting hanya dengan tautan atau nomor kamar, Zoom synchronous online formats juga meliputi two-way live broadcast lectures. Webinar Zoom Meet menjadikan kursus online menjadi sangat populer karena menghemat biaya waktu perjalanan, biaya bahan bakar, dan dampaknya terhadap lingkungan. Zoom memiliki biaya finansial yang rendah dan menawarkan pengalaman yang bagus, memungkinkan untuk menulis dan berbicara bersama melalui proses. Menurut Abdillah (2020) menyatakan bahwa Webinar Zoom Meet dapat digunakan dalam opsi pendidikan jarak jauh, Discussions were two-way audio-visual. Webinar Zoom Meet digunakan untuk telemedicine kesehatan dalam menanggapi pandemi Covid-19 2020, untuk diskusi berbasis komunitas, dll. Tapi dengan banyaknya fitur bukan berarti platform ini terlepas dari keluhan, justru platform ini memiliki banyak keluhan dan yang paling dominan adalah keluhan borosnya kuota yang dipakai selama pembelajaran jarak jauh.

Sehubungan dengan gender, kelompok gender yang pertama yaitu laki-laki memiliki ketertarikan terhadap kegiatan investigasi serta unggul dalam bidang penalaran dan mekanika. Menurut Kelompok Maccoby \& Jacklyn gender yang kedua yaitu perempuan unggul dalam ketepatan, ketelitian, kecermatan dan berpikir secara seksama (Devi, 2017). Perempuan memiliki prestasi dalam hal verbal dan menulis. Para ahli seperti Meece dan Scantlebury (Devi, 2017) secara umum setuju bahwa hasil belajar yang diakibatkan oleh perbedaan gender adalah hasil bias gender di rumah dan lingkungan sekolah. Hasil penelitian menunjukkan bahwa secara umum, orangtua memiliki harapan lebih besar agar anak laki-laki berhasil dalam matematika dan sains dibandingkan anak perempuan mereka. Para orang tua percaya bahwa anak laki-laki memiliki kemampuan yang lebih baik daripada anak perempuan dalam matematika dan sains, sehingga tidak mengejutkan jika anak laki-laki lebih banyak menempuh Pendidikan di ilmu fisika dan mesin dan memiliki gelar sarjana komputer dan sains informasi, sains fisik dan biologi, permesinan, dan matematika. 
Kesimpulannya, perbedaan perlakuan pada laki-laki dan perempuan di rumah dan sekolah memiliki pengaruh besar terhadap identitas dan perkembangan akademik siswa. Sebagai praktisi yang reflektif, guru hendaknya menyikapi dengan baik mengenai harapan dan bias yang mungkin guru miliki untuk memberikan perlakuan yang setara pada kedua jenis sex. Meskipun laki-laki dan perempuan memiliki karakteristik yang berbeda, guru harus memberikan siswa kesempatan dan dorongan yang sama dalam pembelajaran. Berdasarkan uraian yang telah dipaparkan maka di ajukan sebuah studi penelitian dengan judul "Pengaruh Pembelajaran Daring Pengguna Platform Digital Terhadap Pemecahan Masalah Matematis dan Sikap Kritis Siswa di MA Daar El Qolam".

\section{METODE PENELITIAN}

Metode penelitian yang digunakan dalam penelitian ini adalah eksperimen kuasi (quasi experiment). Penelitian ini dilaksanakan di MA Daar El Qolam 1 dan MA Daar El Qolam 4 yang berlokasi di Ds. Pasirgintung, Kec. Jayanti, Kab. Tangerang. Populasi dalam penelitian ini adalah seluruh siswa kelas X MA Daar El Qolam 1 dan MA Daar El Qolam 4 semester genap Tahun Ajaran 2019/2020 dengan karakteristik populasi penelitian yaitu sekolah swasta yang berasrama dan akreditasi A. Sampel terpilih 4 kelas dengan siswa sebanyak 96 siswa yang dipilih dengan teknik Cluster Random Sampling.

Desain yang digunakan dalam penelitian ini terkait pembelajaran matematika berbasis $e$ learning pengguna Webinar Zoom dan WhatsApp Group dengan gender terhadap pemecahan masalah siswa adalah desain factorial 2 × 2 seperti yang ditunjukkan pada Tabel 1 di bawah ini.

Tabel 1. Faktorial 2 x 2 Keterkaitan Pengguna

WhatsApp Group dan Webinar Zoom dengan Gender

\begin{tabular}{ccc}
\hline \multirow{2}{*}{ Gender $(\mathrm{B})$} & \multicolumn{2}{c}{$\begin{array}{c}\text { Pembelajaran Matematika } \\
\text { Berbasis E-learning }(\mathrm{A})\end{array}$} \\
\cline { 2 - 3 } & $\begin{array}{c}\text { Webinar } \\
\text { Zoom }\left(\mathrm{A}_{1}\right)\end{array}$ & $\begin{array}{c}\text { WhatsApp } \\
\text { Group }\left(\mathrm{A}_{2}\right)\end{array}$ \\
\hline $\begin{array}{c}\text { Perempuan } \\
\left(\mathrm{B}_{1}\right)\end{array}$ & $\mathrm{A}_{1} \mathrm{~B}_{1}$ & $\mathrm{~A}_{2} \mathrm{~B}_{1}$ \\
Laki-laki $\left(\mathrm{B}_{2}\right)$ & $\mathrm{A}_{1} \mathrm{~B}_{2}$ & $\mathrm{~A}_{2} \mathrm{~B}_{2}$ \\
\hline
\end{tabular}

Sedangkan desain yang digunakan dalam penelitian ini terkait pembelajaran matematika berbasis e-learning pengguna Webinar Zoom dan WhatsApp Group terhadap sikap kritis adalah desain factorial 2 x 1 seperti yang ditunjukkan pada Tabel 2 di bawah ini. 
Tabel 2. Desain Faktorial 2 x 1 Keterkaitan

Pengguna Webinar Zoom dan WhatsApp Group

\begin{tabular}{cc}
\hline \multicolumn{2}{c}{ Sikap Kritis Siswa terhadap Matematika } \\
Berbasis E-learning $(\mathrm{C})$ \\
\hline Webinar Zoom & WhatsApp Group \\
$\left(C_{1}\right)$ & $\left(\mathrm{C}_{2}\right)$ \\
\hline
\end{tabular}

Keterangan:

$\mathrm{A}_{1}$ :Kelompok siswa yang belajar matematika berbasis e-learning pengguna Webinar Zoom.

$\mathrm{A}_{2}$ :Kelompok siswa yang belajar matematika berbasis e-learning pengguna WhatsApp Group.

$\mathrm{B}_{1}$ : Kelompok siswa perempuan.

$\mathrm{B}_{2}$ : Kelompok siswa laki-laki.

$\mathrm{C}_{1}$ : Sikap kritis siswa yang belajar matematika berbasis e-learning pengguna Webinar Zoom.

$\mathrm{C}_{2}$ : Sikap kritis siswa yang belajar matematika berbasis e-learning pengguna WhatsApp Group.

$\mathrm{A}_{1} \mathrm{~B}_{1}$ : Kelompok siswa perempuan yang belajar matematika berbasis e-learning pengguna Webinar Zoom.

$\mathrm{A}_{2} \mathrm{~B}_{1}$ : Kelompok siswa perempuan yang belajar matematika berbasis $e$-learning pengguna WhatsApp Group.

$\mathrm{A}_{1} \mathrm{~B}_{2}$ : Kelompok siswa laki-laki yang belajar matematika berbasis e-learning pengguna Webinar Zoom.

$\mathrm{A}_{2} \mathrm{~B}_{2}$ : Kelompok siswa laki-laki yang belajar matematika berbasis e-learning pengguna WhatsApp Group.

Desain penelitian yang digunakan yaitu posttest-only control design (Sugiyono, 2009: 76).

Dalam desain ini terdapat dua kelompok yang masing-masing dipilih secara random (R) yaitu kelas eksperimen $1\left(\mathrm{E}_{1}\right)$ dan kelas eksperimen $2\left(\mathrm{E}_{2}\right)$. Kelas eksperimen 1 adalah kelas yang belajar matematika berbasis e-learning pengguna Webinar Zoom. Sedangkan kelas eksperimen 2 adalah kelas yang belajar matematika berbasis e-learning pengguna WhatsApp Group. Setelah kedua kelompok sampel diberi perlakuan yang berbeda maka dilakukan tes kemampuan pemecahan masalah $(\mathrm{O})$ dalam bentuk tes esai. Kelompok eksperimen 1 terdiri dari 47 siswa dengan 24 laki-laki dan 23 perempuan yang mendapat perlakuan belajar matematika berbasis $e$ learning pengguna Webinar Zoom. Kelompok eksperimen 2 terdiri dari 49 orang siswa dengan 25 laki-laki dan 24 perempuan yang mendapat perlakuan belajar matematika berbasis e-learning 
pengguna WhatsApp Group. Sebelum dilakukan pengambilan sampel terlebih dahulu dilakukan analisis data awal siswa. Adapun data awal yang dianalisis yaitu nilai tes kenaikan kelas VII. Analisis data awal yang dilakukan terdiri dari uji normalitas, uji homogenitas dan uji kesamaan rata-rata. Adapun desain posttest only control dapat dilihat pada Tabel berikut.

Tabel 3. Desain Posttest-Only Control Design

Keterangan:

\begin{tabular}{cccc}
\hline \multicolumn{2}{c}{ Kelompok } & Treatment & Tes \\
\hline $\mathrm{E}_{1}$ & $(\mathrm{R})$ & $\mathrm{X}_{1}$ & $\mathrm{O}$ \\
$\mathrm{E}_{2}$ & $(\mathrm{R})$ & $\mathrm{X}_{2}$ & $\mathrm{O}$ \\
\hline
\end{tabular}

$\mathrm{E}_{1}=$ Kelas eksperimen yang belajar matematika berbasis e-learning pengguna Webinar Zoom.

$\mathrm{E}_{2} \quad=$ Kelas eksperimen yang belajar matematika berbasis e-learning pengguna WhatsApp Group.

$\mathrm{X}_{1}=$ Perlakuan berupa pembelajaran matematika berbasis e-learning dengan Webinar Zoom.

$\mathrm{X}_{2}=$ Perlakuan berupa pembelajaran matematika berbasis e-learning dengan WhatsApp Group.

$\mathrm{O}=$ Pemberian tes kemampuan pemecahan masalah matematis dan Sikap kritis.

$\mathrm{R}=$ Proses pemilihan subjek pada kedua kelas secara random.

Teknik pengumpulan data dalam penelitian ini adalah tes dan dokumentasi. Tes digunakan untuk mengumpulkan data kemampuan pemecahan masalah matematis dan dokumentasi digunakan untuk mengumpulkan data kemampuan awal siswa. Instrumen penelitian yang digunakan pada penelitian ini adalah tes kemampuan pemecahan masalah matematis menurut tahapan Polya yang terdiri memahami masalah, membuat rencana dan melaksanakan rencana dari 5 soal uraian. Indikator kemampuan pemecahan masalah matematis yaitu: (1) Menentukan himpunan penyelesaian persamaan linear dua variabel, (2) Menentukan penyelesaian sistem persamaan linear dua variabel dengan cara grafik, substitusi dan eliminasi, (3) Dapat membuat model matematika dari masalah sehari-hari yang berkaitan dengan sistem persamaan linear dua variabel. Sedangkan tes sikap kritis yang dimaksud dalam penelitian ini merujuk pada dua ahli yaitu: 1) menurut Fisher (1993) adalah terampil mengingat, memahami, menerapkan, menganalisis, menyintesis (menggeneralisasi dan mengintegrasikan), dan mengevaluasi, 2) menurut Brown dan Keeley dalam Jacobsen, Eggen dan Kauchak (2009) adalah kesadaran akan sederet pertanyaan-pertanyaan kritis yang saling berhubungan, kemampuan bertanya dan 
menjawab pertanyaan-pertanyaan kritis, dan keinginan untuk secara aktif mengajukan pertanyaan-pertanyaan kritis.

Perhitungan uji hipotesis dilakukan dengan analisis varian (ANAVA) dua jalur 2 x 2 dengan tujuan mengetahui main effect dan interaction effect dari penelitian yang dilakukan. Main effect penelitian ini adalah pengaruh pembelajaran daring pengguna platform Webinar Zoom terhadap pemecahan masalah matematis dibandingkan dan pembelajaran daring pengguna platform WhatsApp Group. Interaction effect penelitian ini adalah interaksi antara pembelajaran daring sebagai variabel perlakuan (A) dengan gender sebagai variabel moderator (B). Jika interaksi A dan B signifikan maka dilanjutkan dengan menguji simple effect (efek sederhana) A pada level $\mathrm{B}_{1}$ dan $\mathrm{B}_{2}$ (perbedaan $\mathrm{A}_{1}$ dan $\mathrm{A}_{2}$ pada level $\mathrm{B}_{1}$ dan $\mathrm{B}_{2}$ ) dengan menggunakan uji lanjut $t$-Dunnet. Uji lanjut $t$-Dunnet digunakan untuk mengetahui mana di antara dua kelompok sampel yang berbeda secara signifikan.

Hipotesis penilaian sebagai berikut: 1) Kemampuan pemecahan masalah matematis siswa yang belajar dengan pembelajaran daring pengguna Webinar Zoom lebih tinggi dibandingkan dengan siswa yang belajar dengan pembelajaran daring pengguna platform WhatsApp Group, 2) Terdapat interaksi antara pembelajaran daring pengguna platform digital dengan gender terhadap pemecahan masalah matematis, 3) Kemampuan pemecahan masalah matematis siswa perempuan yang belajar dengan pembelajaran daring pengguna platform Webinar Zoom lebih tinggi daripada pembelajaran daring pengguna platform WhatsApp Group, 3) Kemampuan pemecahan masalah matematis siswa laki-laki yang belajar dengan pembelajaran daring pengguna platform Webinar Zoom lebih rendah daripada pembelajaran daring pengguna platform WhatsApp Group, 5) Sikap kritis siswa yang belajar dengan pembelajaran daring pengguna platform Webinar Zoom lebih tinggi daripada pembelajaran daring pengguna platform WhatsApp Group.

\section{HASIL DAN PEMBAHASAN}

\section{Hasil}

Berikutnya diberikan penyajian data secara lebih detail pada masing-masing kelompok sampel penelitian sesuai dengan rancangan penelitian yang dilakukan. Penyajian data diberikan dalam bentuk Tabel 4 seperti di berikut ini. 
Tabel 4. Hasil Kemampuan Pemecahan Masalah Siswa

\begin{tabular}{|c|c|c|c|c|}
\hline \multirow{2}{*}{$\begin{array}{c}\text { Gender } \\
\text { (B) }\end{array}$} & \multirow{2}{*}{ Nilai } & \multicolumn{2}{|c|}{$\begin{array}{l}\text { Pembelajaran Matematika } \\
\text { Berbasis } e \text {-learning (A) }\end{array}$} & \multirow{2}{*}{ Jumlah } \\
\hline & & $\begin{array}{r}\text { Webinar } \\
\text { Zoom }\left(\mathrm{A}_{1}\right)\end{array}$ & $\begin{array}{l}\text { WhatsApp } \\
\text { Group }\left(\mathrm{A}_{2}\right)\end{array}$ & \\
\hline \multirow{6}{*}{$\begin{array}{l}\text { Perempuan } \\
\quad\left(\mathrm{B}_{1}\right)\end{array}$} & Rataan & 60,43 & 49,70 & 55,07 \\
\hline & $\sum$ & 23,00 & 24,00 & 47,00 \\
\hline & $\bar{S}$ & 26,28 & 35,87 & 31,08 \\
\hline & $\sigma$ & 356,62 & 563,95 & 460,28 \\
\hline & $x_{\text {maks }}$ & 100,00 & 95,00 & 100,00 \\
\hline & $x_{\min }$ & 45,00 & 20,00 & 20,00 \\
\hline \multirow{6}{*}{$\begin{array}{l}\text { Laki-laki } \\
\quad\left(\mathrm{B}_{2}\right)\end{array}$} & Rataan & 52,92 & 49,00 & 50,96 \\
\hline & $\sum$ & 24,00 & 23,00 & 47,00 \\
\hline & $\bar{S}$ & 28,17 & 27,15 & 27,66 \\
\hline & $\sigma$ & 394,59 & 321,38 & 357,98 \\
\hline & $x_{m a k s}$ & 100,00 & 80,00 & 100,00 \\
\hline & $x_{\min }$ & 15,00 & 20,00 & 15,00 \\
\hline \multirow{6}{*}{ Jumlah } & Rataan & 56,68 & 49,35 & 53,02 \\
\hline & $\sum$ & 47,00 & 47,00 & 94,00 \\
\hline & S & 27,23 & 31,51 & 29,37 \\
\hline & $\sigma$ & 357,61 & 442,67 & 400,14 \\
\hline & $x_{\text {maks }}$ & 100,00 & 95,00 & 100,00 \\
\hline & $x_{\min }$ & 15,00 & 20,00 & 15,00 \\
\hline
\end{tabular}

Sedangkan rincian data sikap kritis siswa pada masing-masing kelompok sesuai dengan rancangan seperti tersaji pada Tabel 5 berikut ini.

Tabel 5. Hasil Sikap Kritis Siswa

\begin{tabular}{ccc}
\hline \multirow{3}{*}{ Nilai } & \multicolumn{2}{c}{ Sikap Kritis Siswa terhadap Pembelajaran Matematika } \\
& \multicolumn{2}{c}{$(\mathrm{C})$} \\
& WhatsApp Group $\left(C_{l}\right)$ & Webinar Zoom $\left(\mathrm{C}_{2}\right)$ \\
\hline Rataan & 113,47 & 95,76 \\
$\sum_{\mathrm{S}}$ & 47,00 & 47,00 \\
$\boldsymbol{\sigma}$ & 15,90 & 13,67 \\
$\boldsymbol{x}_{\text {maks }}$ & 156,21 & 178,63 \\
$x_{\text {min }}$ & 142,00 & 125,00 \\
\hline
\end{tabular}

Uji prasyarat analisis meliputi uji normalitas dengan menggunakan uji KolmogorovSmirnov dan uji homogenitas dengan menggunakan uji Levene. Hasil perhitungan uji normalitas kemampuan pemecahan masalah matematis dan sikap kritis siswa pada kelas yang belajar matematika berbasis e-learning pengguna WhatsApp Group dan kelas yang belajar matematika berbasis e-learning pengguna Webinar Zoom adalah sebagai berikut. 
Tabel 6. Uji Normalitas terhadap Kemampuan Pemecahan

Masalah dan Sikap Kritis Siswa

\begin{tabular}{lrrrr}
\hline \multirow{2}{*}{ Kelompok } & \multicolumn{3}{c}{ Kolmogorov-Smirnov } & \multirow{2}{*}{ Kesimpulan } \\
\cline { 2 - 4 } & Statistic & df & \multicolumn{1}{c}{ Sig. } & \\
\hline $\mathrm{A}_{1} \mathrm{~B}_{1}$ & 0,865 & 23 & 0,056 & Normal \\
$\mathrm{A}_{1} \mathrm{~B}_{2}$ & 0,919 & 23 & 0,274 & Normal \\
$\mathrm{A}_{2} \mathrm{~B}_{1}$ & 0,960 & 24 & 0,778 & Normal \\
$\mathrm{A}_{2} \mathrm{~B}_{2}$ & 0,909 & 24 & 0,206 & Normal \\
$\mathrm{A}_{1}$ & 0,873 & 47 & 0,072 & Normal \\
$\mathrm{A}_{2}$ & 0,865 & 47 & 0,056 & Normal \\
$\mathrm{C}_{1}$ & 0,200 & 47 & 0,280 & Normal \\
$\mathrm{C}_{2}$ & 0,121 & 47 & 0,086 & Normal \\
\hline
\end{tabular}

Hasil perhitungan Tabel 6 di atas menunjukkan bahwa data tersebut mencapai sig. > 0,05. Hal ini berarti bahwa seluruh kelompok data berasal dari populasi yang terdistribusi normal. Pengujian homogenitas varian dilakukan terhadap semua kelompok data pengujian homogenitas dilakukan pada varian pasangan kelompok data $A_{1}, A_{2}, A_{1} B_{1}, A_{1} B_{2}, A_{2} B_{1}, A_{2} B_{2}$ dengan analisis SPSS 23.00 dilakukan dengan taraf signifikan $\alpha=0,05$. Berikut ini diberikan Tabel 5 data hasil uji homogenitas.

Tabel 7. Uji Homogenitas Pemecahan Masalah dan Sikap Kritis Siswa

\begin{tabular}{llc}
\hline \multicolumn{1}{c}{ Kelompok } & Sig. & Kesimpulan \\
\hline $\mathrm{A}_{1} \mathrm{~B}_{1}, \mathrm{~A}_{1} \mathrm{~B}_{2}, \mathrm{~A}_{2} \mathrm{~B}_{1}, \mathrm{~A}_{2} \mathrm{~B}_{2}$ & 0,556 & Homogen \\
$\mathrm{A}_{1}, \mathrm{~A}_{2}$ & 0,184 & Homogen \\
$\mathrm{C}_{1}, \mathrm{C}_{2}$ & 0,878 & Homogen \\
\hline
\end{tabular}

Berdasarkan ketiga kelompok data diperoleh nilai sig. > 0,05 sehingga dapat disimpulkan bahwa seluruh kelompok data berasal dari populasi yang terdistribusi normal dan memiliki varian yang homogen. Dengan demikian persyaratan normalitas dan homogenitas data terpenuhi sehingga dapat digunakan analisis varian (ANAVA) dalam pengujian hipotesis penelitian. Perhitungan data skor tes kemampuan pemecahan masalah matematis dengan ANAVA dua jalur sebagai berikut.

Tabel 8. Hasil Uji ANAVA Dua Jalan Pembelajaran Matematika Berbasis E-learning dengan Gender Serta Interaksi Terhadap Kemampuan Pemecahan Masalah Matematis

\begin{tabular}{lrrrrl}
\hline \multicolumn{1}{c}{ Source } & \multicolumn{1}{c}{ Jk } & \multicolumn{1}{c}{ dk } & \multicolumn{1}{c}{ Rk } & \multicolumn{1}{c}{ F } & \multicolumn{1}{l}{ Sig. } \\
\hline Media (A) & 3524,375 & 3 & 3524,375 & 33,550 & 0,000 \\
Gender (B) & 24,495 & 1 & 24,495 & 0,233 & 0,031 \\
Media* Gender & 1,723 & 1 & 1,723 & 0,016 & 0,038 \\
Galat & 22375,389 & 93 & 105,049 & & \\
Total & 814556,542 & 97 & & & \\
\hline
\end{tabular}


Kemampuan pemecahan masalah matematis siswa.

Berdasarkan kelompok data di atas menunjukkan harga $F_{\text {hitung }}=33,550$ dengan $p$-value $=0,000$ maka $0,000<0,05$ dan $\mathrm{H}_{0}$ di tolak sehingga data ini membuktikan bahwa kemampuan pemecahan masalah matematis siswa yang belajar menggunakan pembelajaran matematika berbasis e-learning pengguna platform Webinar Zoom berbeda dengan kemampuan pemecahan masalah matematis siswa yang belajar menggunakan pembelajaran matematika berbasis $e$ learning pengguna platform WhatsApp Group.

Nilai rata-rata kelompok kemampuan pemecahan masalah siswa pengguna platform Webinar Zoom memiliki rataan sebesar 56,68 lebih tinggi daripada kemampuan pemecahan masalah siswa pengguna platform WhatsApp Group memiliki rataan sebesar 49,35. Hal ini menunjukkan terdapat perbedaan yang signifikan pada kemampuan pemecahan masalah matematis siswa. Berdasarkan pembahasan di atas dapat disimpulkan bahwa kemampuan pemecahan masalah siswa pengguna platform Webinar Zoom lebih tinggi daripada kemampuan pemecahan masalah siswa pengguna platform WhatsApp Group.

Kelompok eksperimen 1, selama proses pembelajaran siswa pengguna Webinar Zoom pemberian keterangan, proses pemahaman definisi dan konsep dilakukan secara langsung oleh siswa secara individual melalui materi yang telah disajikan di dalam web dengan contoh-contoh latihan pemecahan masa-lah juga telah dimuat bersama materi. Apabila siswa telah selesai mempelajari materi dan contoh pemecahan yang ada, maka guru memberikan kesempatan tanya jawab. Kemudian yang dapat dilakukan adalah adanya penguatan yakni melalui latihan dan kemudian pemberian kuis untuk mengukur keberhasilan siswa. Melalui Webinar Zoom semua langkah tersebut dapat terakomodasi dalam sebuah media pembelajaran berbasis web yang dapat diterapkan pada pembelajaran jarak jauh. Proses pemahaman serta pembentukan definisi dan konsep siswa dapat dilakukan me-lalui penyajian materi matematika dalam berbagai format penyajian, bisa melalui bacaan berformat word, HTML ataupun animasi. Untuk setiap pertemuan, tampilan course matematika di situs Webinar Zoom yang digunakan dalam pembelajaran disusun berurutan mulai dari materi serta contoh soal, kemudian soal latihan, dan kuis.

Kelompok eksperimen 1, selama proses pembelajaran siswa pengguna WhatsApp Group Pembelajaran Jarak Jauh (PJJ) bisa dilakukan oleh siswa dan guru yang tergabung dalam satu grup tertentu. Pembelajaran ini bisa dilakukan sesuai dengan kebutuhan dan kesepakatan dari 
guru dan siswanya. Pembelajaran Jarak Jauh (PJJ) bisa terjadi, apabila ada pertemuan yang guru itu tidak bisa untuk mengajar, kemudian memberikan pengumuman kepada siswa supaya nanti malam untuk bisa melangsungkan PJJ tersebut. WhatsApp digunakan sebagai media untuk berdiskusi. Awalnya guru memberikan materi kepada para siswanya yang ada di grup tersebut, kemudian guru memberikan instruksi untuk mengerjakan soal atau berpendapat mengenai materi tersebut. Ketika siswa mengemukakan gagasan atau pendapatnya, harus disertai dengan nama dan nomor absen, supaya guru bisa memberikan penilaian kepada seluruh siswa yang berpartisipasi di dalam grup secara langsung. Pembelajaran ini akan lebih menarik apabila semua siswa aktif dalam pembelajaran tersebut. Guru di sini dituntut harus kreatif dalam mengembangkan materi yang akan diajarkan melalui Pembelajaran Jarak Jauh (PJJ) menggunakan WhatsApp. Fitur dari WhatsApp yang lain adalah bisa mengirim Voice notes atau perekam suara. Perekam suara bisa digunakan untuk siswa dalam mengemukakan pendapatnya. Apabila ada tes kemampuan berbicara, siswa bisa menggunakan fitur voice notes. Penilaian dari guru bisa berupa bagaimana siswa mengutarakan pendapatnya tersebut secara lisan menggunakan fitur voice notes (perekam suara).

Namun berdasarkan pada hasil penelitian ini sejalan dengan penelitian yang dilakukan oleh Suryadi dkk (2018) menjelaskan bahwa WhatsApp mempengaruhi disiplin dan hasil belajar siswa, sehingga aktivitas belajar siswa menurun dan lemah dalam mengikuti pembelajaran. Sependapat dengan penelitian dari Alqahtani dkk (2018), menunjukkan bahwa penggunaan media sosial, seperti WhatsApp dapat memungkinkan siswa untuk memahami dan terlibat dalam menggunakannya sebagai bagian dari pembelajaran apabila dilakukan dengan metode yang lebih menarik. Serta hal ini sejalan dengan hasil penelitian yang dilakukan oleh Sahidillah (2019), mengemukakan bahwa tingkat literasi digital siswa dengan media sosial WhatsApp masih kurang. Jadi dapat disimpulkan bahwa kemampuan pemecahan masalah matematis siswa yang belajar dengan pembelajaran daring pengguna Webinar Zoom lebih tinggi dibandingkan dengan siswa dengan pembelajaran daring pengguna platform WhatsApp Group.

Interaksi antara pembelajaran daring terhadap gender dalam pemecahan masalah matematis.

Hasil perhitungan ANAVA dua jalur diperoleh nilai signifikansi interaksi antara pembelajaran daring pengguna platform digital dengan gender yaitu $0,000<0,05$ dan $\mathrm{H}_{0}$ di tolak sehingga data ini membuktikan bahwa terdapat pengaruh interaksi antara pembelajaran 
daring pengguna platform digital dengan gender terhadap pemecahan masalah matematis. Pernyataan ini didukung oleh perhitungan rata-rata nilai kemampuan pemecahan masalah matematis kelompok siswa perempuan yang belajar menggunakan pembelajaran daring pengguna platform Webinar Zoom adalah 60,43 sedangkan pembelajaran daring pengguna platform WhatsApp Group adalah 49,70. Hal ini berarti bahwa kemampuan pemecahan masalah matematis siswa perempuan yang belajar dengan pembelajaran daring pengguna platform Webinar Zoom lebih tinggi daripada siswa perempuan yang belajar dengan pembelajaran daring pengguna platform WhatsApp Group. Sedangkan rata-rata nilai kemampuan pemecahan masalah matematis kelompok siswa laki-laki yang belajar menggunakan pembelajaran daring pengguna platform Webinar Zoom adalah 52,92 sedangkan pembelajaran daring pengguna platform WhatsApp Group adalah 49,00. Hal ini berarti tidak ada perbedaan yang signifikan antara kemampuan pemecahan masalah matematis siswa laki-laki yang belajar dengan pembelajaran daring pengguna platform Webinar Zoom dengan siswa laki-laki yang belajar dengan pembelajaran daring pengguna platform WhatsApp Group.

Berdasarkan data yang diketahui bahwa kemampuan pemecahan siswa perempuan dan siswa laki-laki lebih cocok belajar menggunakan pembelajaran daring pengguna Webinar Zoom secara langsung dibandingkan pembelajaran daring pengguna WhatsApp Group karena memungkinkan perbedaan self-efficacy dan sikap kritis siswa dalam menyikapi proses pembelajaran di masing-masing platform tidaklah sama. Seperti hal nya pada kelas eksperimen 1 pengguna platform Webinar Zoom kegiatan diskusi dan transfer pengetahuan secara face-toface layaknya bertemu langsung menjadikan guru dan siswa untuk bertemu dan berinteraksi secara virtual dengan fasilitas pesan instan dan kegiatan presentasi sedangkan pada eksperimen 2 pengguna WhatsApp Group diskusi pengetahuan hanya dapat dilakukan dengan mengirim pesan teks, gambar, video dan file dalam berbagai format kepada semua anggota dan sifatnya terkesan memberi tugas tanpa bimbingan secara langsung.

Intinya pembelajaran online pengguna pal form digital menuntut peran guru mengevaluasi efektivitas dan disesuaikan dengan kebutuhan belajar. Ini penting dilakukan untuk tetap memenuhi aspek pembelajaran seperti proses pengetahuan, moral, keterampilan, kecerdasan dan estetika. Mengingat bahwa perubahan ke pembelajaran online secara tidak langsung berpengaruh pada daya serap siswa. Penting untuk diperhatikan yakni komunikasi orang tua dan guru untuk mewujudkan kemandirian belajar siswa selama masa pandemi Covid- 
19 dan hal ini perlu di evaluasi serta disesuaikan dengan kondisi setempat, mengingat kemampuan orang tua memberikan fasilitas pembelajaran online berbeda. Kuncinya adalah memaksimalkan kemampuan siswa belajar dalam kondisi pandemi seperti ini.

\section{Kemampuan pemecahan masalah berdasarkan gender pada pembelajaran daring}

Berdasarkan pengujian hipotesis ketiga, $\mathrm{H}_{0}$ ditolak yang berarti rerata kemampuan pemecahan masalah matematis siswa perempuan yang belajar dengan pembelajaran daring pengguna platform Webinar Zoom pengguna platform WhatsApp Group memperoleh perbedaan yang signifikan. Rata-rata nilai kemampuan pemecahan masalah matematis siswa perempuan yang belajar dengan pembelajaran daring pengguna platform Webinar Zoom sebesar 60,43 lebih tinggi daripada pembelajaran daring pengguna platform WhatsApp Group sebesar 49,70. Berdasarkan pembahasan sebelumnya dikemukakan bahwa temuan di lapangan dan hasil sebaran kuesioner proses kemampuan pemecahan masalah perempuan yang belajar dengan pembelajaran daring pengguna platform Webinar Zoom diketahui banyak kelebihan saat melakukan pembelajaran dengan Webinar Zoom yang menunjang penyampaian materi sehingga menjadi lebih efektif dibandingkan dengan WhatsApp Group.

Pada kelas eksperimen 1 pembelajaran dengan Webinar Zoom yang menunjang penyampaian materi sehingga menjadi lebih efektif ini sesuai dengan penelitian Jaka dan Hamidah (2020) yang menyatakan bahwa pembelajaran dengan Webinar Zoom yang menunjang penyampaian materi sehingga menjadi lebih efektif dibandingkan dengan WA Group diantaranya: 1) materi bisa lebih mudah dipahami karena guru menerangkan secara langsung materi yang disampaikan, 2) siswa bisa bertanya dan berdiskusi dengan leluasa seperti saat pembelajaran di kelas, 3) pertanyaan dari siswa juga dapat langsung direspon saat itu juga sehingga lebih efektif dan mudah dipahami oleh siswa, 4) siswa tidak merasa bosan dengan materi yang disampaikan/dijelaskan guru karena tatap muka secara langsung, 5) keaktifan siswa dapat terlihat dan terpantau, sehingga siswa terdorong untuk lebih fokus dan tidak membuka aplikasi lain selama proses pembelajaran, dan 6) adanya fitur penjadwalan dan rekaman, fitur chat dan video kualitas HD menjadi fasilitas yang menunjang proses pembelajaran sehingga pada proses diskusi memberi kesempatan kepada siswa untuk berdiskusi langsung dengan guru sehingga pemahaman mereka yang keliru dapat segera diperbaiki secara langsung dan dapat mengurangi kebingungan yang mungkin dialami oleh siswa pada saat mereka mengalami 
kegagalan dalam memahami ataupun mengingat pelajaran serta dapat memberikan informasi yang cukup untuk memperbaiki kesalahan yang lebih kompleks. Dengan demikian pemecahan masalah terhadap pemahaman konsep serta prestasi belajar siswa mengalami perubahan secara positif.

Pada kelas eksperimen 1 pembelajaran dengan WhatsApp Group, guru mengamati kegiatan dan diskusi yang terjadi di dalam kelas. Guru tidak terlalu banyak terlibat dalam diskusi yang dilakukan oleh siswa. Pada saat guru menyadari adanya kesalahan konsep ataupun perhitungan yang dilakukan oleh hampir sebagian besar siswa, selanjutnya guru memberikan review secara umum untuk memperbaiki kesalahan tersebut. Dengan demikian siswa dituntut untuk mampu menerjemahkan petunjuk guru serta menemukan jawaban perbaikan secara mandiri. Adapun kelemahan dari pembelajaran dengan WhatsApp Group ialah siswa kurang memahami bagian mana dari jawaban mereka yang salah. Berdasarkan pembahasan di atas disimpulkan bahwa kemampuan pemecahan masalah matematis siswa perempuan yang belajar dengan pembelajaran daring pengguna platform Webinar Zoom lebih tinggi daripada pembelajaran daring pengguna platform WhatsApp Group.

Berdasarkan penelitian, sikap kritis siswa yang belajar dengan pembelajaran daring pengguna platform Webinar Zoom lebih tinggi daripada pembelajaran daring pengguna platform WhatsApp Group. Hasil analisis data menunjukkan bahwa terdapat perbedaan yang signifikan antara sikap kritis siswa antara yang belajar dengan pembelajaran daring pengguna platform Webinar Zoom dengan pembelajaran daring pengguna platform WhatsApp Group. Hal ini menunjukkan bahwa sikap kritis siswa yang belajar dengan pembelajaran daring pengguna platform Webinar Zoom lebih tinggi daripada pembelajaran daring pengguna platform WhatsApp Group. Selama proses belajar mengajar berlangsung, baik pada kelas eksperimen 1 maupun eksperimen 2, siswa berdiskusi untuk menemukan pengetahuan baru berdasarkan pengetahuan yang telah dimiliki sebelumnya.

Pada kelas eksperimen 1, siswa terlihat sangat antusias dalam mengikuti pelajaran. Hal ini terlihat dari keaktifan dan sikap kritis siswa dalam berdiskusi mengerjakan soal yang diberikan. Siswa lebih percaya diri dalam menanyakan hal-hal yang belum mereka pahami baik kepada guru maupun dengan temannya. Dengan demikian melalui interaksi dan komunikasi antar siswa maka dengan sendirinya terjadi transfer ilmu dari siswa kepada siswa lainnya. Perlakuan yang 
diberikan ini memberi dampak positif dalam mengembangkan kemampuan matematika siswa khususnya kemampuan pemecahan masalah matematis.

Pada kelas eksperimen 2, hanya sebagian siswa yang terlibat aktif dalam diskusi kelas. Siswa mudah putus asa dan mengandalkan teman lainnya. Hal ini berakibat beberapa soal dengan tingkat kesulitan tinggi tidak dikerjakan oleh siswa. Adapun faktor lain yang mempengaruhi keberhasilan siswa dalam belajar adalah sikap kritis siswa. Semakin tinggi sikap kritis siswa semakin besar usaha yang dilakukannya dalam menyelesaikan tugas. Demikian hal nya dalam belajar matematika, siswa yang memiliki sifat mandiri tinggi merasa bertanggung jawab atas prestasinya, memiliki harapan sukses yang besar dan semangat yang tinggi dalam mengerjakan tugas-tugas yang diberikan. Sedangkan siswa dengan mandiri rendah cenderung membatasi diri untuk berpartisipasi dalam kelompok ataupun memulai percakapan dengan teman sebayanya.

Jika dihubungkan antara pembelajaran daring pengguna platform digital dengan sikap kritis siswa, maka berdasarkan salah satu ciri utama menunjang proses pembelajaran yang dilakukan oleh siswa diarahkan untuk memecahkan masalah matematis dan sikap kritis siswa. Dengan demikian dapat dikatakan bahwa melalui pembelajaran daring pengguna platform digital dan sikap kritis siswa dalam belajar semakin bertumbuh dan menciptakan tanggungjawab siswa dalam mengerjakan tugas-tugas guru secara mandiri. Dengan demikian dapat dikatakan bahwa pada prinsipnya penggunaan media ICT betul-betul berdampak positif terhadap siswa dalam proses pembelajaran. Senada apa yang disampaikan oleh Yaniawati, Kartasasmita, dan Saputra (2019) menjelaskan bahwa pemanfaatan e-learning dalam matematika memiliki pengaruh positif. Selain sebagai upaya memecahkan masalah teknis dan sebagai media pembelajaran e-learning juga bisa menjadi upaya untuk mengatasi masalah pembelajaran yang substansial sebagai bahan pembelajaran.

Maka dapat disimpulkan sikap kritis siswa yang belajar dengan pembelajaran daring pengguna platform Webinar Zoom lebih tinggi daripada pembelajaran daring pengguna platform WhatsApp Group.

\section{Sikap kritis siswa dalam pembelajaran daring}

Hasil analisis data menunjukkan bahwa terdapat perbedaan yang signifikan antara sikap kritis siswa antara yang belajar dengan pembelajaran daring pengguna platform Webinar Zoom 
dengan pembelajaran daring pengguna platform WhatsApp Group. Hal ini menunjukkan bahwa sikap kritis siswa yang belajar dengan pembelajaran daring pengguna platform Webinar Zoom lebih tinggi daripada pembelajaran daring pengguna platform WhatsApp Group. Selama proses belajar mengajar berlangsung, baik pada kelas eksperimen 1 maupun eksperimen 2, siswa berdiskusi untuk menemukan pengetahuan baru berdasarkan pengetahuan yang telah dimiliki sebelumnya.

Pada kelas eksperimen 1, siswa terlihat sangat antusias dalam mengikuti pelajaran. Hal ini terlihat dari keaktifan dan sikap kritis siswa dalam berdiskusi mengerjakan soal yang diberikan. Siswa lebih percaya diri dalam menanyakan hal-hal yang belum mereka pahami baik kepada guru maupun dengan temannya. Dengan demikian melalui interaksi dan komunikasi antar siswa maka dengan sendirinya terjadi transfer ilmu dari siswa kepada siswa lainnya. Perlakuan yang diberikan ini memberi dampak positif dalam mengembangkan kemampuan matematika siswa khususnya kemampuan pemecahan masalah matematis.

Pada kelas eksperimen 2, hanya sebagian siswa yang terlibat aktif dalam diskusi kelas. Siswa mudah putus asa dan mengandalkan teman lainnya. Hal ini berakibat beberapa soal dengan tingkat kesulitan tinggi tidak dikerjakan oleh siswa. Adapun faktor lain yang mempengaruhi keberhasilan siswa dalam belajar adalah sikap kritis siswa. Semakin tinggi sikap kritis siswa semakin besar usaha yang dilakukannya dalam menyelesaikan tugas. Demikian hal nya dalam belajar matematika, siswa yang memiliki sifat mandiri tinggi merasa bertanggung jawab atas prestasinya, memiliki harapan sukses yang besar dan semangat yang tinggi dalam mengerjakan tugas-tugas yang diberikan. Sedangkan siswa dengan mandiri rendah cenderung membatasi diri untuk berpartisipasi dalam kelompok ataupun memulai percakapan dengan teman sebayanya.

Jika dihubungkan antara pembelajaran daring pengguna platform digital dengan sikap kritis siswa, maka berdasarkan salah satu ciri utama menunjang proses pembelajaran yang dilakukan oleh siswa diarahkan untuk memecahkan masalah matematis dan sikap kritis siswa. Dengan demikian dapat dikatakan bahwa melalui pembelajaran daring pengguna platform digital dan sikap kritis siswa dalam belajar semakin bertumbuh dan menciptakan tanggungjawab siswa dalam mengerjakan tugas-tugas guru secara mandiri. Dengan demikian dapat dikatakan bahwa pada prinsipnya penggunaan media ICT betul-betul berdampak positif terhadap siswa dalam proses pembelajaran. Senada apa yang disampaikan oleh Yaniawati, Kartasasmita, dan 
Saputra (2019) menjelaskan bahwa pemanfaatan e-learning dalam matematika memiliki pengaruh positif. Selain sebagai upaya memecahkan masalah teknis dan sebagai media pembelajaran e-learning juga bisa menjadi upaya untuk mengatasi masalah pembelajaran yang substansial sebagai bahan pembelajaran. Dapat disimpulkan sikap kritis siswa yang belajar dengan pembelajaran daring pengguna platform Webinar Zoom lebih tinggi daripada pembelajaran daring pengguna platform WhatsApp Group.

\section{Diskusi}

Berdasarkan pengujian hipotesis keempat diketahui bahwa tidak terdapat perbedaan antara kemampuan pemecahan masalah matematis siswa laki-laki yang belajar menggunakan pembelajaran daring pengguna Webminar Zoom dengan siswa laki-laki yang belajar menggunakan pembelajaran daring pengguna WhatsApp Group. Rata-rata kemampuan pemecahan masalah matematis pada kelompok siswa laki-laki yang belajar menggunakan pembelajaran daring pengguna platform Weniar Zoom dengan siswa laki-laki yang belajar menggunakan pembelajaran daring pengguna WhatsApp Group tidak menunjukkan perbedaan yang signifikan. Rata-rata nilai kemampuan pemecahan masalah matematis siswa laki-laki yang belajar menggunakan pembelajaran daring pengguna platform Weniar Zoom sebesar 56,68 sedangkan siswa laki-laki yang belajar menggunakan pembelajaran daring pengguna WhatsApp Group sebesar 49,35. Hasil analisis data menunjukkan bahwa kemampuan pemecahan masalah matematis kelompok siswa laki-laki yang belajar menggunakan pembelajaran daring pengguna platform Weniar Zoom dengan siswa laki-laki yang belajar menggunakan pembelajaran daring pengguna WhatsApp Group. tidak menunjukkan perbedaan yang signifikan.

Pada kelas eksperimen 1 dan eksperimen 2, jika ditinjau dari karakteristik laki-laki yang menyenangi kegiatan pembelajaran matematika maka seharusnya mereka memiliki hasil belajar yang baik dalam matematika. Namun hal ini berbeda dengan hasil penelitian yang dilakukan. Pada kelas eksperimen 1 dan eksperimen 2 terlihat siswa laki-laki lebih mudah merasa bosan dengan kegiatan diskusi yang dilakukan dalam rentang waktu lama. Fokus pembicaraan mereka mudah teralihkan oleh hal-hal di luar matematika seperti membicarakan kegiatan olahraga atau permainan yang sedang mereka senangi. Hal ini didukung oleh Allan dan Barbara (2010) yang menyatakan bahwa laki-laki memiliki keterampilan memasang puzzle. Hal ini mengindikasikan bahwa siswa laki-laki lebih menyenangi kegiatan-kegiatan yang banyak melibatkan aktifitas motorik. Namun yang menjadi masalah adalah mereka berhenti pada proses 
mengkomunikasikan idenya saja dan cenderung tidak menyatakannya dalam bentuk lisan sehingga guru tidak dapat mengukur tingkat pemahaman mereka secara langsung.

Faktor lain yang mempengaruhi rendahnya kemampuan pemecahan masalah siswa lakilaki ialah rendahnya rasa ingin tahu dalam memecahkan petunjuk yang diberikan oleh guru. Petunjuk yang telah diberikan oleh guru secara lisan melalui kegiatan diskusi maupun melalui tulisan pada forum diskusi pada pertemuan sebelumnya diabaikan dan tidak dipelajari kembali. Selama proses pembelajaran berlangsung, siswa dituntut untuk mampu menganalisis setiap pernyataan, komentar atau petunjuk yang diberikan oleh guru secara mandiri sehingga mereka dapat memahami dan menemukan pemecahan masalah antar topik dalam matematika. Berdasarkan pembahasan di atas disimpulkan bahwa terdapat faktor internal yang mempengaruhi kemampuan pemecahan masalah matematis siswa seperti ketekunan, motivasi dan daya juang. Sehingga dapat disimpulkan kemampuan pemecahan masalah matematis siswa laki-laki yang belajar dengan pembelajaran daring pengguna Webinar Zoom lebih tinggi daripada pembelajaran daring pengguna platform WhatsApp Group.

\section{KESIMPULAN}

Berdasarkan hasil penelitian dan pembahasan mengenai pengaruh pembelajaran daring pengguna platform digital terhadap pemecahan masalah matematis dan sikap kritis siswa maka diperoleh beberapa kesimpulan sebagai berikut: (1) Kemampuan pemecahan masalah matematis siswa yang belajar dengan pembelajaran daring pengguna Webinar Zoom lebih tinggi dibandingkan dengan siswa dengan pembelajaran daring pengguna platform WhatsApp Group. (2) Terdapat interaksi antara pembelajaran daring pengguna platform digital dengan gender terhadap pemecahan masalah matematis. (3) Kemampuan pemecahan masalah matematis siswa perempuan yang belajar dengan pembelajaran daring pengguna platform Webinar Zoom lebih tinggi daripada pembelajaran daring pengguna platform WhatsApp Group. (4) Kemampuan pemecahan masalah matematis siswa laki-laki yang belajar dengan pembelajaran daring pengguna platform Webinar Zoom lebih tinggi daripada pembelajaran daring pengguna platform WhatsApp Group. (5) Sikap kritis siswa yang belajar dengan pembelajaran daring pengguna platform Webinar Zoom lebih tinggi daripada pembelajaran daring pengguna platform WhatsApp Group. 


\section{REKOMENDASI}

Kepada peneliti selanjutnya perlu memperhatikan dan mengontrol beberapa faktor internal seperti ketekunan, motivasi dan daya juang yang dapat mempengaruhi keberhasilan mereka dalam belajar. Selain itu perlu dilakukan penelitian secara kualitatif guna mengetahui pengaruh pembelajaran daring pengguna platform digital terhadap pemecahan masalah matematis dan sikap kritis siswa secara lebih dalam dengan didukung oleh transkrip percakapan serta detail treatment yang diberikan kepada siswa.

\section{UCAPAN TERIMAKASIH}

Dalam penyusunan naskah publikasi ilmiah yang sederhana ini, penulis mendapat bantuan dari berbagai pihak, untuk itu penulis mengucapkan terima kasih kepada: Kolaborator dan rekan-rekan para pengajar matematika pondok pesantren Daar El Qolam, Kabupaten Tangerang yang telah membantu untuk penelitian. Akhirnya ucapan terima kasih disampaikan kepada semua pihak yang tidak dapat disebutkan satu persatu.

\section{REFERENSI}

Abdillah, W. (2018). Metode Penelitian Terpadu Sistem Informasi Pemodelan Teoritis, Pengukuran dan Pengujian Statistik. (R. I. Utami, Ed.). Yogyakarta: Penerbit Andi.

Suryadi, A. (2014). Pendidikan Indonesia Menuju 2025. Bandung: PT. Remaja Rosdakarya.

Allan, P. and Barbara, P. (2010). Why Men Lie and Women Cry. Penerjemah. Syafruddin Hasani. Yogyakarta: Dioma.

Alqahtani, M. S., Bhaskar, C. V., Vadakalur Elumalai, K., \& Abumelha, M. (2018). WhatsApp: An Online Platform for University-Level English Language Education. Arab World English Journal, 9(4), 108-121.

Bata, D. (2017). Pengaruh Metode Penemuan Terbimbing Terhadap Kemampuan Koneksi Matematis Ditinjau Gender. Jurnal Ilmiah Pendidikan Matematika, 5(1), 145-154.

Kusuma, J. W. (2020). Perbandingan Hasil Belajar Matematika dengan Penggunaan Platform WhatsApp Group dan Webinar Zoom dalam Pembelajaran Jarak Jauh pada Masa Pandemi Covid-19. Jurnal Ilmiah Pendidikan Matematika, 5(1), 97-105.

Jubile Enterprise. (2012). Rahasia Manajemen File. PT. Elex Media Komputindo: Jakarta. Suryadi, E., Ginanjar, M. H., \& Priyatna, M. (2018). Penggunaan Sosial Media WhatsApp dan 
Pengaruhnya terhadap Disiplin Belajar Peserta Didik pada Mata Pelajaran Pendidikan Agama Islam. Jurnal Edukasi Islami Jurnal Pendidikan Islam, 07(1), 1-22.

Sahidillah, W. (2019). WhatsApp Sebagai Media Literasi Digital Siswa. Journal Varia Pendidikan, 31(1), 52 - 571

Yaniawati, R., P., Kartasasmita, B. G. and Saputra, J. (2019). E-learning assisted problem-based learning for self-regulated learning and mathematical problem solving. Journal of Physics: Conference Series 1280 (4), 042023. DOI: 10.1088/1742-6596/1280/4/042023 